\title{
IAMJ
}

INTERNATIONAL

AYURVEDIC

MEDICAL JOURNAL

\section{STUDY OF NIDANA PANCHAKA OF CONTEMPORARY MADHUMEHA PATIENT vis. a. vis. TYPE II DIABETES MELLITUS}

\author{
$\underline{\text { Lokhande Abhijeet Sahebrao }}^{1}, \underline{\text { Joshi Dnyanesh Sudhakarrao }}^{2}, \underline{\text { Gawai Abhijeet Ashokrao }}^{3}$ \\ ${ }^{1}$ M.D. Rognidan - Vikritivigyan, Assistant Professor (Rognidan - Vikrutivigyan Department) \\ ${ }^{2}$ M.D. Samhita, M.A. Samskrit, Associate Professor (Samhita Siddhant Department) \\ ${ }^{3}$ M.D. Agadtantra, Assistant Professor (Agadtantra Department) \\ Dr. Rajendra Gode Ayurved College, Hospital \& Research Center, Maharashtra, India
}

Corresponding Author: vakratund.lokhande@gmail.com

https://doi.org/10.46607/iamj0908092020

(Published online: September 2020)

Open Access

(C) International Ayurvedic Medical Journal, India 2020

Article Received: 21/08/2020 - Peer Reviewed: 11/09/2020 - Accepted for Publication: 11/09/2020

Check for updates

\begin{abstract}
Junk food and lavish lifestyle is a status statement of today era which is responsible for various type of diseases. Diabetes Mellitus is one of the predominant diseases causing this lifestyle. Diabetes Mellitus resembling with Madhumeha which is one type of Vataj Prameha explained by Acharya Charaka. The ayurvedic protocol of management is very beneficial for prophylaxis and treatment of Madhumeha (Diabetes Mellitus). Madhumeha can be treated more accurately according to the Ayurvedic method of treatment only if its Nidan Panchaka (Etiopathogenesis) is well established.

Aim: To study Nidana Panchaka of contemporary Madhumeha patient vis. a. vis. type II diabetes mellitus.

Material \& Method: In this study, already diagnosed 30 patients of diabetes mellitus type II were selected and the history of those patients was taken according to standard case proforma. Present study is Analytical, Retrospective, Observational, and Cross-sectional type.

Observation: An analyzed data indicated that lavish lifestyle, unhealthy food, and junk food are also the reasons behind disease along with Hetus (Etiological factor) mentioned in the Samhitas (Ayurveda Literature).

Conclusion: It can be concluded that it is possible to establish the Nidan Panchak of Madhumeha vyadhi with the help of Ayurvedic basic principles.
\end{abstract}


Keywords: Madhumeh, Diabetes mellitus, Nidan Panchak, Vataj prameha

\section{INTRODUCTION}

Ayurveda is an ancient science and it is Shashwat (perpetual) entity. In Ayurveda Rutucharya (Seasonal regime), Dincharya (Daily Regime), Vyayama (Exercise), Aharavidhi Visheshayatana (Eight specific factors of a method of dieting), etc. are mentioned. Now a day people prefer junk food which is more Vidahi (causing Burning sensation) and Abhishandi (Channel blocking) which directly causes Agnimandya (decreases digestive fire). India is the Diabetic capital of the world. ${ }^{1}$ Because As per the present day's restless and stressful lifestyle People don't have time for exercise, so many diseases are the outcome of faulty dietary habits. Madhumeha is one of the diseases formed by the above-mentioned conditions. Madhumeha is a disease that shows Madhura (Sweet), Prabhuta (Large quantity), AvilaMutrata (turbid) ${ }^{2}$. According to acharya Vagbhata, the word Madhumeha is made up of two words 'Madhu' (Honey) and 'Mehati' (Passing of urine) and hence in Madhumeha honey-like urine is passed. According to Ayurveda Madhumeha can be correlated with Diabetes Mellitus Type II. ${ }^{3}$ The term Diabetes mellitus contains two words i.e. 'Diabetes' and 'Mellitus'. In the Greek language, the 'Diabetes' means to run through a siphon and the term Mellitus means honey. ${ }^{4}$ In Ayurveda, Prameha is described as having twenty types based on Prabhut-Avila Mutrata (Excessive and Turbid Urination). Now a day out of these twenty types Madhumeha is mostly seen so it is of utmost importance to know the Samprapti of Madhumeha. The present study is an attempt to elaborate the Nidana Panchaka of disease Madhumeha i.e. Contemporary Hetu (Etiology) along with Granthokt Hetu (Etiology from classical texts), Purvroopa (Prodroma), Roopa (Symptoms), Samprapti (Pathogenesis), Upashaya-Anupashaya (Therapeutic unsuitability suitability).

\section{Material and Method}

Review of Literature - Review of Madhumeha was studied from classical Ayurvedic textbooks. A modern review of diabetes mellitus is taken from an authorized modern textbook. Internet data and various research papers were also explored.

Study Type- Observational, Analytical, Retrospective, Cross-sectional

Table 1: Criteria for selection of patient

Inclusion Criteria
1. Newly Diagnosed 30 patients of Madhumeha (Type II Dia-
betes Mellitus) were selected.
2. Age: - Patients between 30 to 70 years were selected.
3. Patients were selected irrespective of gender, religion and oc-
cupation.

Study Design -

1. Newly diagnosed 30 patients of diabetes mellitus type II were selected irrespective of age, sex, caste, religion, occupation etc.

2. These 30 patients aged above 30 years were selected with the help of blood sugar level tests and urine sugar level tests.

3. Informed written consent was taken from each patient prior to case taking.

\section{Exclusion Criteria}

1. Type 1 diabetes mellitus.

2. Patient with any other major illness. (e.g. Trauma, Infectious wound, Gangrene, HIV, Viral infection viz. congenital rubella, mumps)

3. Gestational diabetes

4. Detailed case of the patients was taken with the help of specially designed case record proforma to find out the Hetus, Purvaroopas, Roopa's of Madhumeha.

5. Further with the help of above data Nidana Panchak of Medhumeha was established on the Ayurvedic basic principles

6. Discussion was done on the basis of the above data.

7. Finally, summary and conclusion were drawn 
Table 2: Criteria for assessment-

\section{Objective Criteria $^{5}$}

1. Fasting blood sugar $\geq 7.0 \mathrm{mmol} / \mathrm{l}$ or $126 \mathrm{mg} / \mathrm{dl}$ or

2. Post prandial blood sugar $\geq 11.1 \mathrm{mmol} / 1$ or $200 \mathrm{mg} / \mathrm{dl}$ or

3. Two-hours plasma glucose $\geq 11.1 \mathrm{mmol} / 1$ or $200 \mathrm{mg} / \mathrm{dl}$ during an oral glucose tolerance test

4. Blood sugar level:- (Also including urine sugar level)

\section{Subjective Criteria ${ }^{6}$}

1. Mootradhikya (Excessive urination)

2. Mootra-aavilata (turbid urination)

3. Dant, Taalu, Gal,Jivha pradeshi malaadhikya (Dirty coating at Teeth, Palate, Throat, Tongue)

4. Hasta tala daha (Burning sensation in Hands)

5. Paada tala daha (Burning sensation in Feet)

6. Trushna aadhikya (Excessive Thirst)

7. Mookha madhurata (Sweetness in mouth)

8. Sarva sharir chhikanata (Excess moisture all over body)

\section{Observations and result}

Table 3: Hetu Observed

\begin{tabular}{|l|l|l|}
\hline NIDANA & No. of Patients & Total Percentage \\
\hline Avyayam (No Exercise) & 28 & $93.33 \%$ \\
\hline Guru Ahara (Heavy diet) & 25 & $83.33 \%$ \\
\hline Katu (Spicy food) & 25 & $83.33 \%$ \\
\hline Mamsa sevan (Meat eating) & 25 & $83.33 \%$ \\
\hline Abhishandi Ahara (Channel blocking food) & 21 & $70.00 \%$ \\
\hline Madhura Ahara (Excess Sweet diet) & 18 & $60 \%$ \\
\hline Asyasukha (Eating just to gratify taste buds) & 18 & $60 \%$ \\
\hline Payansi (Milk Products) & 17 & $56.67 \%$ \\
\hline Ruksha Ahara (Food causing Dryness) & 16 & $53.33 \%$ \\
\hline Dadhini (Curd \& curd products) & 16 & $53.33 \%$ \\
\hline Snigdh Ahara (Unctuous food) & 14 & $46.67 \%$ \\
\hline Vidahi Anna (Food causing burning sensation) & 14 & $46.67 \%$ \\
\hline Manasika Hetu (Psychological causes) & 14 & $46.67 \%$ \\
\hline Adhyashana (Eating before digestion of previous food) & 9 & $30 \%$ \\
\hline Sheeta Ahara (Cold food) & 7 & $23.33 \%$ \\
\hline Swapnasukha (Excess sleeping) & 7 & $23.33 \%$ \\
\hline Medya Drava (Fatty substances) & 6 & $20 \%$ \\
\hline Vishamashan (Irregular dieting) & 4 & $13.33 \%$ \\
\hline
\end{tabular}

Most of the patients show Hetus like Avyayam, Guru Ahara (Heavy for digestion), Katu Ahara (Spicy food) and Mamsa (Meat), Abhishandi Ahara (Channel blocking), Madhura Ahara (Sweet food), Snigdha Ahara
(Unctuous food) and Vidahi Ahara (Food causing burning sensation) like Samosa, Vada-Pav, etc. and presented with Manasika Hetu (Psychological causes) like Chinta (Tension), Krodha (Anger), Shoka (Sadness). Adhyashana (Excessive diet).

Table 4: Purvaroopa (Prodroma) observed

\begin{tabular}{|l|l|l|}
\hline Purvroopa & No. Of Patients & Total Percentage \\
\hline Dant Pradeshi Maladhikya (Dirty coating at Teeth) & 26 & $86.67 \%$ \\
\hline Trushnadhikya (Excessive Thirst) & 25 & $83.33 \%$ \\
\hline Hasta tala daha (Burning sensation in Hands) & 13 & $43.33 \%$ \\
\hline Pada tala daha (Burning sensation in Feet) & 13 & $43.33 \%$ \\
\hline
\end{tabular}




\begin{tabular}{|l|l|l|}
\hline Jivha Pradeshi Maladhikya (Dirty coating at Tongue) & 9 & $30 \%$ \\
\hline Gala Pradeshi Maladhikya (Dirty coating at Throat) & 4 & $13.33 \%$ \\
\hline Alasya (Lethargy) & 4 & $13.33 \%$ \\
\hline Talu Pradeshi Maladhikya (Dirty Coating) & 3 & $10 \%$ \\
\hline Mookha Madhurya (Sweetness in Mouth) & 2 & $6.67 \%$ \\
\hline Kshudhadhikya (Excess Of appetite) & 1 & $3.33 \%$ \\
\hline Atinidra (Excess of Sleep) & 1 & $3.33 \%$ \\
\hline Sarva Sharira Chikkanata (Excess of Moisture all over body) & 0 & $0 \%$ \\
\hline
\end{tabular}

This table shows that Dant Pradeshi Maladhikya (Dirty coating at teeth), Trushnadhikya (Excess thirst), Hata Pada Tala Daha (Burning sensation of feet and hand) were prominent Purvaroopa observed in patients.

Table 5: Roopa observed

\begin{tabular}{|c|c|c|}
\hline Roopa & No. Of Patients & Total Percentage \\
\hline Mutra Adhikya (Excessive urination) & 30 & $100 \%$ \\
\hline Dant Pradeshi Maladhikya (Dirty coating at Teeth) & 28 & $93.33 \%$ \\
\hline Trushnadhikya (Excessive Thirst) & 25 & $83.33 \%$ \\
\hline Mutra Avilata (Turbid urination) & 19 & $63.33 \%$ \\
\hline Hasta Tala Daha (Burning sensation in Hands) & 14 & $46.67 \%$ \\
\hline Pada Tala Daha (Burning sensation in Feet) & 14 & $46.67 \%$ \\
\hline Jivha Pradeshi Maladhikya (Dirty coating at Tongue) & 13 & $43.33 \%$ \\
\hline Gala Pradeshi Maladhikya (Dirty coating at Throat) & 4 & $13.33 \%$ \\
\hline Alasya (Lethargy) & 4 & $13.33 \%$ \\
\hline Talu Pradeshi maladhikya (Dirty coating at Palate) & 3 & $10 \%$ \\
\hline Mookha Madhurya (Sweetness in mouth) & 2 & $6.67 \%$ \\
\hline Kshudhadhikya (Excess of Appetite) & 1 & $3.33 \%$ \\
\hline Atinidra (Excess of Sleep) & 1 & $3.33 \%$ \\
\hline Sarva Sharira Chikkanata (Excess moisture all over body) & 0 & $0 \%$ \\
\hline
\end{tabular}

Most of patients showed Roopa like Mutra Adhikya (Excess of urination), Danta Pradeshi Maladhikya (Dirty coating at teeth), Trushnadhikya (Excess thirst), Mutra Avilata (Turbid urine), Hasta Tala Daha and Pada Tala Daha (Burning sensation of hand and feet), Jivha Pradeshi Maladhikya (Dirty coating at tongue). All above Roopa gives an idea about Tridosha Dushti (Vitiation of Dosha), Agnimandya, Dhatvagnimandya, Kledotpatti, Dhatushaithilya, vitiation of Vata, Madhumeh

\section{DISCUSSION AND CONCLUSION}

Madhumeha is a widely evidential disease since ancient age till today. Evidence as well as occurrence is increasing day by day and bounces with their complications and complexes. Diabetes mellitus is similar to Madhumeha which is a subtype of Vataja Prameha.
Here was an attempt to study Nidan Panchak of contemporary Madhumeha patient viz.a.viz type II diabetes mellitus with the help of this observational, retrospective, cross sectional, and Analytical study as there was not any specific nidan panchaka of Madhumeha was explored by any Acharya. Here already diagnosed 30 patients of diabetes mellitus type II were selected with the help of inclusion and exclusion criteria. These 30 patients were continued during the whole study and case was taken by consent of patient. After analysis of data, most commonly found Hetus were - 93.33\% patients were having Avyayam, 83.33\% patients were having Guru Ahara (Heavy for digestion), Katu ahara (Spicy food) and Mamsa (Meat), 70\% patient were having Abhishandi Ahara (Channel blocking), 60\% patient were having Madhura ahara (Sweet food), 46.67\% patient were having snigdha ahara (Unctuous food) and 
vidahi ahara (Food causing burning sensation) like Samosa, Vadapav etc. and also presented with Manasika hetu (Psychological causes) like Chinta (Tension), Krodha (Anger), Shoka (Sadness). In majority of patients Purvaroopa observed were Dant Pradeshi Maladhikya, Trushnadhikya, Hata Pada Tala Daha. Prominently observed Roopas were Jivha Pradeshi Maladhikya (Dirty coating at tongue-43.33\%). All above Roopas gives an idea about Tridosha Dushti (Vitiation of Dosha), Agnimandya, Dhatvagnimandya, Kledotpatti, Dhatushaithilya, vitiation of Vata, Madhumeha.

The vitiation of Agni not only takes place at Jatharagni level but also at Dhatvagni level. Pradhana Dosha involve in the Vyadhi is Kapha and Dushya involved are Meda along with Rasa, Rakta, Mamsa, Majja, Shukra, Vasa, Lasika, Oja, Mutra. All above Roopa gives an idea about Tridosha Dushti (Vitiation of Dosha), Agnimandya, Dhatvagnimandya, Kledotpatti, Dhatushaithilya, vitiation of Vata, Madhumeh. Hence from the present study it can be conclude that it is possible to establish the Nidan Panchak of Madhumeha Vyadhi with the help of basic Ayurvedic principles.

\section{REFERENCES}

1. Rakesh Malik. India is the diabetic capital of world. Mumbai mirror. 2016 Jun.28 [cited 2020 Jun. 10] In: The Economy Times [internet] Available from: https:/health.economictimes.indiatimes.com/news/diagnostics/india-is-the-diabetes-capital-of-theworld/50757875.

2. Bramhanand Tripathi, Ashtang Hridayam, Nidansthan 10/18, edition 2017, Choukhamba surbharati publication, Varanasi; 497

3. Priyavrat Sharma, Charak Samhita, Vol. I, Nidansthan 4/39, edition 2017, Choukhamba Surbharati publication, Varanasi; 274.

4. Siddhartha N. Shah, Textbook of Medicine, volume II, Section 18 , chapter 3 , edition $8^{\text {th }}$, API publication, Mumbai; 1042

5. Siddhartha N. Shah, Textbook of Medicine, volume II, Section 18 , chapter 3 , edition $8^{\text {th }}$, API publication, Mumbai; 1049

6. Bramhanand Tripathi, Madhav Nidanam, volume II, Uttarardh 33/5 \& 6, edition 2017, Choukhamba surbharati publication, Varanasi; 8 -9

\section{Source of Support: Nil}

\section{Conflict of Interest: None Declared}

How to cite this URL: Lokhande Abhijeet Sahebrao et al: Study Of Nidana Panchaka Of Contemporary Madhumeha Patient Vis. A. Vis. Type Ii Diabetes Mellitus. International Ayurvedic Medical Journal \{online\} 2020 \{cited September, 2020\} Available from: http://www.iamj.in/posts/images/upload/4358_4362.pdf 